\title{
Effects of Temperature and Chemical Composition of Intergranular Glass on Dihedral Angle of Glass-Doped 3Y-TZP
}

\author{
Eiji HIYOSHI, Yutaka SHINODA, Takashi AKATSU and Fumihiro WAKAI \\ Center for Materials Design, Materials and Structures Laboratory, Tokyo Institute of Technology, \\ R3-23, 4259, Nagatsuta, Midori-ku, Yokohama-shi 226-8503 \\ ガラス添加 3Y-TZP の二面角に及ぼす粒界ガラス組成と温度の影響 \\ 日吉英司·篠田 豊·赤津 隆·若井史博 \\ 東京工業大学応用セラミックス研究所構造デザイン研究センター, 226-8503 横浜市緑区長津田町 4259 R3-23
}

\begin{abstract}
The distribution and the morphology of glass phase in polycrystals are affected by the dihedral angle and the volume fraction of the glass phase. The effects of temperature and chemical composition of intergranular glass on dihedral angle of glass-doped 3-mol\%-yttria-stabilized tetragonal zirconia polycrystals (3Y-TZP) were studied by transmission electron microscopy (TEM). The intergranular glass was either $\mathrm{SiO}_{2}$ (melting point of $1700^{\circ} \mathrm{C}$ ) or $\mathrm{Y}_{2} \mathrm{O}_{3}-\mathrm{Al}_{2} \mathrm{O}_{3}-\mathrm{SiO}_{2}$ eutectic glass ( $\mathrm{YAS}$ glass: melting point of $1350^{\circ} \mathrm{C}$ ). The average dihedral angles of $\mathrm{SiO}_{2}$-doped and YAS-doped $3 Y$-TZP, which were sintered at $1300^{\circ} \mathrm{C}$, were found to be $70^{\circ}$ and $50^{\circ}$, respectively. The dihedral angle in YAS-doped 3Y-TZP decreased to $25^{\circ}$ after annealing at $1500^{\circ} \mathrm{C}$, whereas that in $\mathrm{SiO}_{2}$ doped 3Y-TZP remained constant. From the relationship between the dihedral angle and the ratio of grain boundary energy to solid/glass interface energy $\left(\gamma_{\mathrm{SS}} / \gamma_{\mathrm{SL}}\right)$, it was suggested that $\gamma_{\mathrm{SS}} / \gamma_{\mathrm{SL}}$ increased at elevated temperatures higher than the melting point of glass.
\end{abstract}

[Received June 29, 2004; Accepted September 22, 2004]

Key-words : Zirconia, Microstructure, Glass doping, Dihedral angle, Second-phase distribution

\section{Introduction}

Ceramics often contain a glass phase at grain boundaries. The residual glass phase results from the liquid phase sintering with metal oxides as additives. A very small amount of liquidforming impurities in the starting powder also forms a glass phase in some ceramics. ${ }^{1,2)}$ The glass phase promotes mass transport at elevated temperatures, and as such reduces the flow stress. The presence of glass phase affects the deformation behavior of ceramics. ${ }^{3), 4)} 3$-mol\%-yttria-stabilized tetragonal zirconia polycrystals (3Y-TZP) is one of the most typical ceramics that shows superplasticity at elevated temperatures. ${ }^{5)}$ The effects of additional glass on superplasticity of Y-TZP have been studied to improve the ductility ${ }^{6)-11}$ ) Yoshizawa et al. ${ }^{6}$ and Gust et al. ${ }^{7)}$ reported that the additional silicate glass was present not only at multiple junctions as glass pocket but also at two-grain junctions as thin film. However, Ikuhara et al. ${ }^{9}$ revealed that intergranular glass film did not exist in $\mathrm{SiO}_{2}$-doped $\mathrm{Y}$-TZP. No intergranular glass film was present in barium silicate glass doped Y-TZP, and borosilicate glass doped Y-TZP also. ${ }^{11)}$ Zirconia grains in this material, as well as those in undoped $\mathrm{Y}-\mathrm{TZP},{ }^{12)-14)}$ were directly bonded atomically at grain boundaries.

The distribution and the morphology of glass phase in polycrystals are determined by solid/glass interface energy $\left(\gamma_{\mathrm{SL}}\right)$, solid/solid interface energy (grain boundary energy: $\gamma_{\mathrm{SS}}$ ), and volume fraction of glass phase. ${ }^{15)-17)}$ The equilibrium relationship between $\gamma_{\mathrm{SL}}, \gamma_{\mathrm{SS}}$, and dihedral angle $(\phi)$ can be expressed by the following equation ${ }^{18)}$ (Fig. 1)

$$
\frac{\gamma_{\mathrm{SS}}}{\gamma_{\mathrm{SL}}}=2 \cos \frac{\phi}{2}
$$

According to Eq. (1), if the ratio $\gamma_{\mathrm{SS}} / \gamma_{\mathrm{SL}}$ is equal or greater than $2, \phi=0$, and the faces of all grains are completely covered by the glass phase. If the ratio $\gamma_{\mathrm{SS}} / \gamma_{\mathrm{SL}}$ is less than $2(\phi$

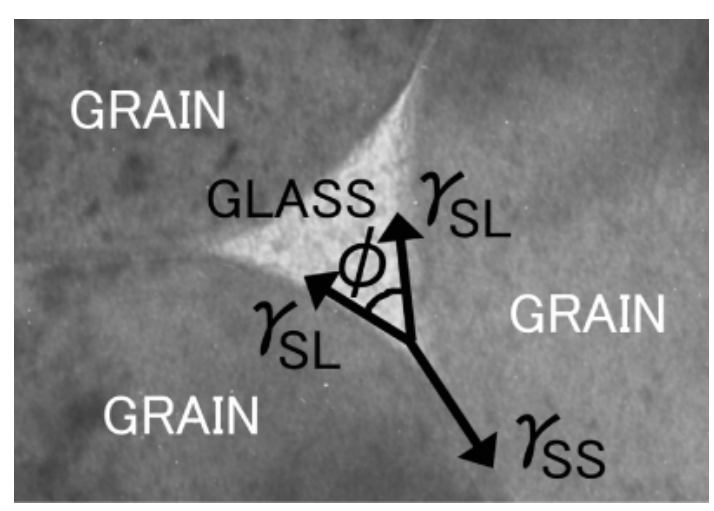

Fig. 1. Dihedral angle $(\phi)$ in multiple pocket of glass-containing ceramic (YAS-doped 3Y-TZP). $\gamma_{\mathrm{SS}}$ is the grain boundary energy, and $\gamma_{\mathrm{SL}}$ is the interface energy between grain and glass.

$>0$ ), the grains are partly covered by the glass phase and uncovered grain boundaries are formed. This uncovered area fraction increases with increasing the dihedral angle $\phi$. Zhao et al. ${ }^{19)}$ reported that the dihedral angle in $\mathrm{SiO}_{2}$-doped Y-TZP decreased with increasing temperature. The dihedral angle in glass-doped Y-TZP will be dependent not only on temperature but also on composition of glass phase. In this report we studied the effect of temperature and chemical composition of glass on the dihedral angle in glass-doped $3 \mathrm{Y}-\mathrm{TZP}$.

\section{Experimental procedure}

2.1 Materials preparation

The materials were prepared from a high-purity 3Y-TZP powder (TZ-3Y, Tosoh Co.) containing $3 \mathrm{~mol} \% \mathrm{Y}_{2} \mathrm{O}_{3}$. The impurities in $3 \mathrm{Y}-\mathrm{TZP}$ powder were $<0.005$ mass $\% \mathrm{Al}_{2} \mathrm{O}_{3}$, 

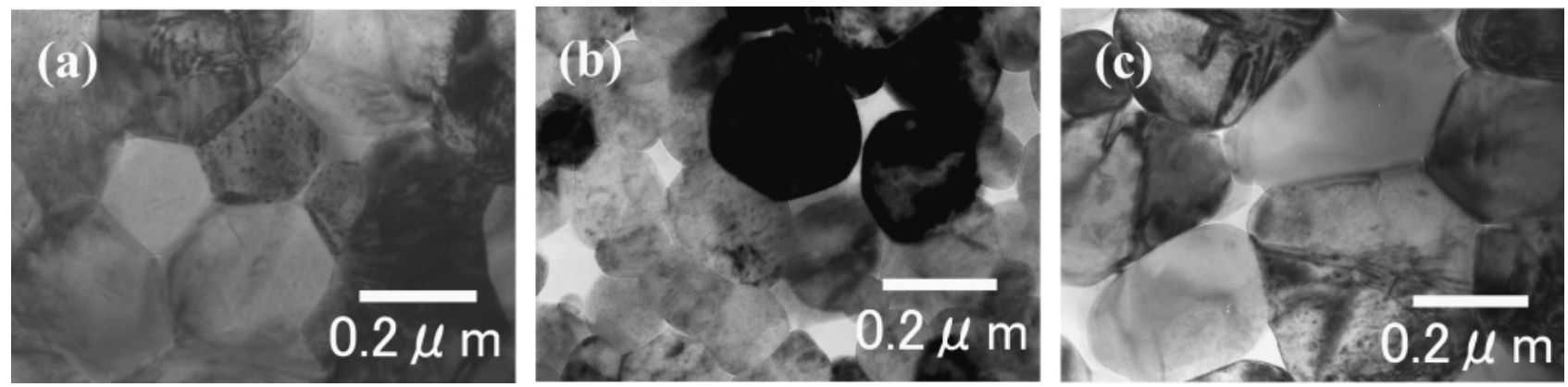

Fig. 2. TEM micrographs of as-sintered (a) undoped 3Y-TZP, (b) $\mathrm{SiO}_{2}$-doped 3Y-TZP, and (c) YAS-doped 3Y-TZP).

$<0.005$ mass $\% \quad \mathrm{SiO}_{2}, \quad<0.002$ mass $\% \quad \mathrm{Fe}_{2} \mathrm{O}_{3}$, and 0.023 mass $\% \mathrm{Na}_{2} \mathrm{O}$. Two different glasses were used as additives, which had different melting points (m.p.): one a $\mathrm{SiO}_{2}$ glass (m.p. of $1700^{\circ} \mathrm{C}$ ) and the other $\mathrm{Y}_{2} \mathrm{O}_{3}-\mathrm{Al}_{2} \mathrm{O}_{3}-\mathrm{SiO}_{2}$ eutectic glass (YAS glass: m.p. of $1350^{\circ} \mathrm{C}^{20)}$ ). The chemical composition of YAS glass was 42 mass $\% \quad \mathrm{Y}_{2} \mathrm{O}_{3}, 25$ mass $\% \quad \mathrm{Al}_{2} \mathrm{O}_{3}$, and 33 mass $\% \mathrm{SiO}_{2}$. Two kinds of materials were prepared: (1) 5 mass $\%$ (12 vol\%) $\mathrm{SiO}_{2}$-doped $3 \mathrm{Y}-\mathrm{TZP}$, (2) 5 mass $\%$ (9 vol\%) YAS glass-doped 3Y-TZP. Colloidal silica (Nissan Chemical Industries Ltd.) was used as $\mathrm{SiO}_{2}$ glass. The $\mathrm{Y}_{2} \mathrm{O}_{3}-$ $\mathrm{Al}_{2} \mathrm{O}_{3}-\mathrm{SiO}_{2}$ eutectic glass (YAS glass), ${ }^{21)}$ was prepared from $\mathrm{Y}_{2} \mathrm{O}_{3}$ powder (Shin-Etsu Chemical Co.), $\mathrm{Al}_{2} \mathrm{O}_{3}$ powder (AKP-50, Sumitomo Chemical Co.), and $\mathrm{SiO}_{2}$ powder (Kojundo Chemical Lab., Co.). The homogeneous starting powder mixture of YAS glass was melted in a platinum crucible at $1600^{\circ} \mathrm{C}$ for $2 \mathrm{~h}$ and quenched in air. The obtained glass batch was ground in a Y-TZP pot with Y-TZP balls and anhydrous ethanol for $10 \mathrm{~h}$ at a speed of 250 r.p.m. using a planetary ball-mill. The 3Y-TZP powder was mixed with 5 mass $\%$ glass powder in a ball mill for $24 \mathrm{~h}$, and dried. The mixed powders were pressed into bars under a pressure of 30 $\mathrm{MPa}$, and then, cold isostatically pressed under a pressure of $200 \mathrm{MPa}$ to obtain green bodies. The compacts were sintered at $1300^{\circ} \mathrm{C}$ for $2 \mathrm{~h}$ in air. Archimedes method was used for measuring densities of sintered bodies and YAS glass batches. The true densities of glasses were $2.3 \mathrm{~g} / \mathrm{cm}^{3}$ for $\mathrm{SiO}_{2}$, and 3.5 $\mathrm{g} / \mathrm{cm}^{3}$ for YAS. Bulk densities of the samples were found to be $5.58 \mathrm{~g} / \mathrm{cm}^{3}$ for $\mathrm{SiO}_{2}$-doped $3 \mathrm{Y}-\mathrm{TZP}$, and $5.56 \mathrm{~g} / \mathrm{cm}^{3}$ for YASdoped 3Y-TZP. All the samples used in this study had final densities higher than $97 \%$ of the theoretical value. In order to study the effects of annealing on microstructures, the sintered bodies were heated in the temperature range from $1300^{\circ} \mathrm{C}$ to $1500^{\circ} \mathrm{C}$ for $2 \mathrm{~h}$ in air, and cooled rapidly at a rate of $200^{\circ} \mathrm{C} /$ min to below $900^{\circ} \mathrm{C}$.

2.2 Microstructural characterization

Scanning electron microscopy (SEM) was used to characterize the microstructures of the as-sintered samples. For SEM observation, samples were mechanically polished and then thermally etched at $1250^{\circ} \mathrm{C}$ for $10 \mathrm{~min}$ in air. The average grain size was measured by using the mean linear intercept method. Samples for transmission electron microscopy (TEM) were prepared using a standard technique. Sintered bodies were cut and mechanically ground to get disks of $3 \mathrm{~mm}$ diameter. They were subsequently ground to a thickness of 50 $\mu \mathrm{m}$, dimpled to a thickness of $10 \mu \mathrm{m}$, and ion-milled to electron transparency at $5 \mathrm{kV}$. These samples were clipped by copper grids with carbon coating. Observations were done at a voltage of $200 \mathrm{kV}$ on a JEM-2000EX (JEOL).

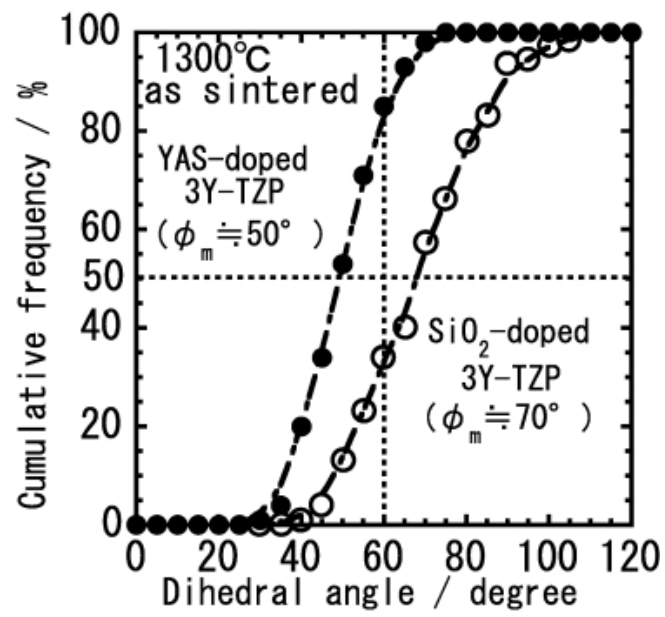

Fig. 3. Cumulative distribution function of the observed dihedral angles in as-sintered glass-doped 3Y-TZP. The average dihedral angle $\left(\phi_{\mathrm{m}}\right)$ are $70^{\circ}$ for $\mathrm{SiO}_{2}$-doped $3 \mathrm{Y}-\mathrm{TZP}$, and $50^{\circ}$ for YAS-doped 3Y-TZP.

\section{Results and discussion}

Figure 2(a) shows a typical TEM micrograph of undoped $3 \mathrm{Y}-\mathrm{TZP}$ sintered at $1400^{\circ} \mathrm{C}$ for $2 \mathrm{~h}$ in air. The average grain size was measured to be $0.35 \mu \mathrm{m}$. Figures 2 (b) and (c) show TEM micrographs of the glass-doped $3 \mathrm{Y}-\mathrm{TZP}$, i.e., $\mathrm{SiO}_{2-}$ doped 3Y-TZP and YAS-doped 3Y-TZP, respectively. The average grain sizes obtained from the SEM photographs of the as-sintered bodies were $0.25 \mu \mathrm{m}$ for $\mathrm{SiO}_{2}$-doped $3 \mathrm{Y}-\mathrm{TZP}$, and $0.35 \mu \mathrm{m}$ for YAS-doped 3Y-TZP. All zirconia grains in the three samples were equiaxed. The grains in undoped 3Y-TZP were faceted with sharp triple junctions. However, the grains in glass-doped 3Y-TZP were rounded in their corners, and glass pockets were found at the multiple junctions.

In order to measure dihedral angles $\phi$ in glass-doped 3Y-TZP, tangential lines were drawn at a glass pockets as illustrated in Fig. 1.22),23) More than 100 dihedral angles were measured in each sample. Figure 3 shows the cumulative distribution function of the dihedral angles in glass-doped $3 \mathrm{Y}-\mathrm{TZP}$ which were sintered at $1300^{\circ} \mathrm{C}$. The average dihedral angles $\left(\phi_{\mathrm{m}}\right)$ were defined as the dihedral angle of $50 \%$ point on the cumulative distribution function, and they were found to be $70^{\circ}$ and $50^{\circ}$ for $\mathrm{SiO}_{2}$-doped $3 \mathrm{Y}$-TZP and YAS-doped $3 \mathrm{Y}-\mathrm{TZP}$, respectively. When a small amount of the second phase, i.e., glass phase, is present in a polycrystalline microstructure, its distribution amongst the primary grain is critically dependent on the dihedral angle. ${ }^{15)-18)}$ When the dihedral angle is smaller than $60^{\circ}$, a small amount of liquid forms a 


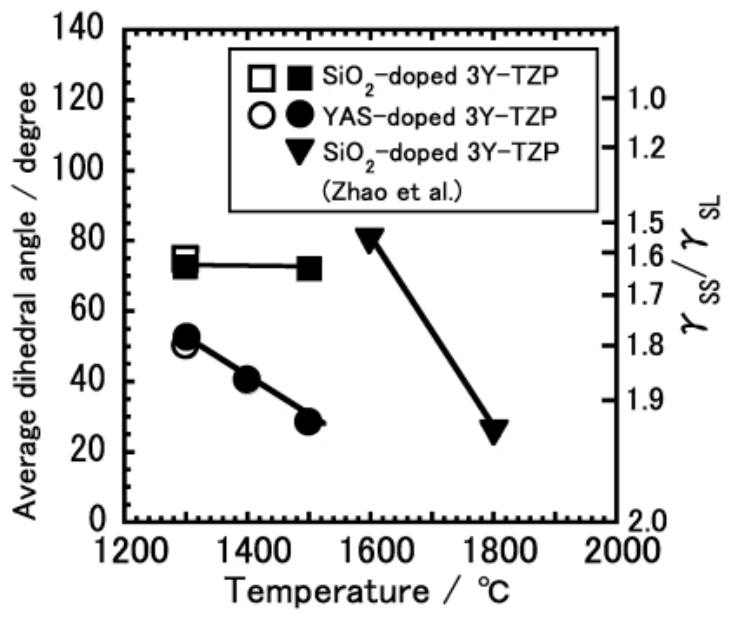

Fig. 4. Plot of average dihedral angle as a function of annealing temperature. ( $\square$ as-sintered $\mathrm{SiO}_{2}$-doped 3Y-TZP, $\square$ annealed $\mathrm{SiO}_{2}$ doped 3Y-TZP, $\bigcirc$ as-sintered YAS-doped 3Y-TZP, $\bigcirc$ annealed YAS-doped 3Y-TZP, $\nabla$ Zhao's results on $\mathrm{SiO}_{2}$-doped $3 \mathrm{Y}-\mathrm{TZP}^{19)}$ ).

continuous skeleton along the grain edges. ${ }^{18)}$ The average dihedral angle in YAS-doped $3 \mathrm{Y}-\mathrm{TZP}$ was less than $60^{\circ}$, then the intergranular YAS glass can be an interconnected each other.

While no significant grain growth was observed in $\mathrm{SiO}_{2}$ doped $3 \mathrm{Y}-\mathrm{TZP}$ after annealing at $1500^{\circ} \mathrm{C}$ for $2 \mathrm{~h}$, the average grain size of YAS-doped 3Y-TZP increased from $0.35 \mu \mathrm{m}$ to $0.64 \mu \mathrm{m}$. It is supposed that the diffusion through interconnected glass phase can enhance the grain growth of YASdoped 3Y-TZP. The constituent atoms in glass phase, i.e., $\mathrm{Y},{ }^{13), 14)} \mathrm{Si}^{9), 24)}$ and $\mathrm{Al}^{24), 25)}$ segregate at grain boundaries of Y-TZP. The segregated atoms affects grain boundary diffusion and the grain boundary energy $\left(\gamma_{\mathrm{SS}}\right)$. No significant grain growths were found in YAS-doped $3 \mathrm{Y}$-TZP after annealing at temperatures lower than $1400^{\circ} \mathrm{C}$ for $2 \mathrm{~h}$.

Figure 4 shows the relationship between the average dihedral angles and the annealing temperature. The vertical axis on the right hand shows the ratio $\gamma_{\mathrm{SS}} / \gamma_{\mathrm{SL}}$. In the temperature range from $1300^{\circ} \mathrm{C}$ to $1500^{\circ} \mathrm{C}$, the average dihedral angles in $\mathrm{SiO}_{2}$-doped $3 \mathrm{Y}$-TZP remained constant at about $70^{\circ}$, whereas those in YAS-doped 3Y-TZP decreased with increasing temperature. The average dihedral angle in YAS-doped 3Y-TZP decreased to about $25^{\circ}$ at $1500^{\circ} \mathrm{C}$, which was higher than the melting point of YAS glass. Zhao's results on 5 mass $\% \mathrm{SiO}_{2}$ doped $\mathrm{Y}_{-} \mathrm{TZP}^{19)}$ were also shown in Fig. 4 for comparison. The average dihedral angle of $\mathrm{SiO}_{2}$-doped $3 \mathrm{Y}$-TZP decreased to $30^{\circ}-40^{\circ}$ at $1800^{\circ} \mathrm{C}$, which was higher than the melting point of $\mathrm{SiO}_{2}$. According to Eq. (1), the dihedral angle $\phi$ depends on the ratio $\gamma_{\mathrm{SS}} / \gamma_{\mathrm{SL}}$. The temperature dependence of the average dihedral angle suggests that $\gamma_{\mathrm{SS}} / \gamma_{\mathrm{SL}}$ increases at temperatures higher than the melting point of intergranular glass. Since the effect of temperature on grain boundary energy is smaller than that on solid/liquid interface energy, ${ }^{26)}$ the increase of $\gamma_{\mathrm{SS}} / \gamma_{\mathrm{SL}}$ is probably due to the decrease of $\gamma_{\mathrm{SL}}$ at temperatures higher than the melting point.

The dihedral angle changes with increasing temperature in other liquid-containing oxides and metals also. Gambino et al. ${ }^{27)}$ studied the effect of annealing on the dihedral angle of $\mathrm{Bi}$-rich intergranular phase in $\mathrm{ZnO}$ varistor. The dihedral angles were decreased with the rise in annealing temperature. Above the eutectic point in the $\mathrm{Bi}_{2} \mathrm{O}_{3}-\mathrm{ZnO}$ system (about $780^{\circ} \mathrm{C}$ ), the dihedral angle became zero, and all $\mathrm{ZnO}$ grains were completely covered by the second phase. The increase of $\mathrm{ZnO}$ concentration in the second phase caused the decrease of the dihedral angle with increasing temperature. Ikeuye and Smith ${ }^{28)}$ also reported the decrease in dihedral angle with increasing temperature in $\mathrm{Al}-\mathrm{Sn}$ and $\mathrm{Cu}-\mathrm{Pb}$ systems. According to those reports, $\gamma_{\mathrm{SL}}$ decreased around the eutectic point because of chemical composition changes in the second phase. Cheng and Thompson ${ }^{29)}$ reported that the zirconia solubility in $\mathrm{Y}_{2} \mathrm{O}_{3}-\mathrm{Al}_{2} \mathrm{O}_{3}-\mathrm{SiO}_{2}$ glass increased with increasing temperature. Therefore, we conclude that the increase in zirconia concentration in the glass phase decrease the $\gamma_{\mathrm{SL}}$ in YAS-doped $3 \mathrm{Y}-\mathrm{TZP}$ at temperatures higher than the melting point of the glass.

\section{Conclusions}

The effect of temperature and chemical composition of intergranular glass on dihedral angle of glass-doped 3Y-TZP were studied by transmission electron microscopy. The following results were obtained:

(1) The average dihedral angle of YAS-doped 3Y-TZP was $50^{\circ}$, and that of $\mathrm{SiO}_{2}$-doped $3 \mathrm{Y}$-TZP was $70^{\circ}$.

(2) The grain size of YAS-doped 3Y-TZP increased from $0.35 \mu \mathrm{m}$ to $0.64 \mu \mathrm{m}$ after annealing at $1500^{\circ} \mathrm{C}$ for $2 \mathrm{~h}$, while no significant grain growth was observed in $\mathrm{SiO}_{2}$-doped $3 \mathrm{Y}$-TZP.

(3) The dihedral angle of YAS-doped 3Y-TZP decreased to $25^{\circ}$ at $1500^{\circ} \mathrm{C}$. It was suggested that $\gamma_{\mathrm{SS}} / \gamma_{\mathrm{SL}}$ increased at elevated temperature higher than the melting point of glass.

\section{References}

1) German, R. M., "Liquid Phase Sintering," Plenum Press (1985) pp. 3-11.

2) Raj, R., J. Am. Ceram. Soc., Vol. 64, pp. 245-248 (1981).

3) Wilkinson, D. S., J. Am. Ceram. Soc., Vol. 81, pp. 275-299 (1998).

4) Meléndez-Martínez, J. J. and Dominguez-Rodriguez, A., Prog. Mater. Sci., Vol. 49, pp. 19-107 (2004).

5) Wakai, F., Sakaguchi, S. and Matsuno, Y., Adv. Ceram. Mater., Vol. 1, pp. 259-263 (1986).

6) Yoshizawa, Y. and Sakuma, T., J. Am. Ceram. Soc., Vol. 73, pp. 3069-3073 (1990).

7) Gust, M., Goo, G., Wolfenstine, J. and Mecartney, M. L., J. Am. Ceram. Soc., Vol. 76, pp. 1681-1690 (1993).

8) Kajihara, K., Yoshizawa, Y. and Sakuma, T., Acta. Metall. Mater., Vol. 43, pp. 1235-1242 (1995).

9) Ikuhara, Y., Thavorniti, P. and Sakuma, T., Acta Mater., Vol. 45, pp. 5275-5284 (1997).

10) Sakka, Y. and Hiraga, K., J. Chem. Soc. Jpn., Vol. 8, pp. 497-507 (1999) [in Japanese].

11) Imamura, P. H., Evans, N. D., Sakuma, T. and Mecartney, M. L., J. Am. Ceram. Soc., Vol. 83, pp. 3095-3099 (2000).

12) Nieh, T. G. and Wandsworth, J., Acta Metall. Mater., Vol. 38, pp. 1121-1133 (1990).

13) Primdahl, S., Thölen, A. and Langdon, T. G., Acta Metall. Mater., Vol. 43, pp. 1211-1218 (1995).

14) Hines, J. A., Ikuhara, Y., Chokshi, A. H. and Sakuma, T., Acta Mater., Vol. 46, pp. 5557-5568 (1998).

15) Wray, P. J., Acta Metall., Vol. 24, pp. 125-135 (1975).

16) Beere, W., Acta Metall., Vol. 23, pp. 131-138 (1975).

17) Svoboda, J., Riedel, H. and Zipse, H., Acta Metall. Mater., Vol. 42, pp. 435-443 (1994).

18) Kingery, W. D., Bowen, H. K. and Uhlmann, D. R., "Introduction to Ceramics (Second ed.)," A Wiley-Interscience Publication (1975) pp. 212-215.

19) Zhao, J., Ikuhara, Y. and Sakuma, T., J. Am. Ceram. Soc., Vol. 81, pp. 2087-2092 (1998).

20) Bondar, I. A. and Galakov, F. Y., Izv. Akad. Nauk. SSSR Ser Khim., Vol. 7, pp. 1325-1326 (1964).

21) Makishima, A., Tamura, Y. and Sakaino, T., J. Am. Ceram. 
Soc., Vol. 61, pp. 247-249 (1978).

22) Harker, D. and Perker, E. R., Trans. ASM., Vol. 34, pp. 156-201 (1945).

23) Rigger, O. K. and Van Vlack, L. H., Trans. AIME., Vol. 218, pp. 933-935 (1960).

24) Thavorniti, P., Ikuhara, Y. and Sakuma, T., J. Am. Ceram. Soc., Vol. 81, pp. 2927-2932 (1998).

25) Sato, E., Morioka, H., Kuribayashi, K. and Sundararaman, D., J. Mater. Sci., Vol. 34, pp. 4511-4518 (1999).
26) Chalmers, B., Christian, J. W. and Massalski, T. B., Prog. Mater. Sci., Vol. 16, pp. 13-42 (1972).

27) Gambino, J. P., Kingery, W. D., Pike, G. E., Levinson, L. M. and Philipp, H. R., J. Am. Ceram. Soc., Vol. 72, pp. 642-645 (1989).

28) Ikeuye, K. K. and Smith, C. S., Trans. AIME., Vol. 185, pp. 762-768 (1949).

29) Cheng, Y. and Thompson, D. P., Br. Ceram. Trans. J., Vol. 87, pp. 107-110 (1988). 